\title{
THE DISTRIBUTION OF CAREX BUXBAUMII WAHLENB. IN POLAND
}

\author{
ZOFIA SOTEK \\ Department of Botany and Nature Conservation \\ University of Szczecin \\ Felczaka 3c, 71-412 Szczecin, Poland \\ e-mail:sotek@univ.szczecin.pl
}

(Received: September 19, 2005. Accepted: February 2, 2006)

\begin{abstract}
The distribution of Carex buxbaumii Wahlenb. in Poland is described, based on herbarium materials. The list of localities with brief description of its taxonomic characteristics, habitat and general distribution have also been included.
\end{abstract}

KEY WORDS: Buxbaums sedge, endangered taxa, distribution, Caricetum buxbaumii.

\section{INTRODUCTION}

The reports published hitherto on Carex buxbaumii in Poland have been rather scarce and concerned mainly the localities in Lubelski region (Fijałkowski, Chojnacka-Fijałkowska 1990) near Lake Miedwie (Jasnowski 1962; Bacieczko 1996) and in the Wigierski National Park (Jutrzenka-Trzebiatowski et al. 2001), specifying the locality and sometimes habitat conditions. The distribution of $C$. buxbaumii in Poland has not been fully recognized yet. In the "Atlas of vascular plants distribution in Poland" (Zając and Zając 2001), a complex map of C. buxbaumii aggregate was given as this species is often mistaken for C. hartmanii. These sedges are of similar shape and similar habitat demands. Moreover, they can mix. The available keys for identification of the species usually do not give a complete set of features differentiating these two taxons. The most complete taxonomic distribution with the features characterising exclusively $C$. buxbaumii was given by Egorova (1999). In view of the above, the aim of the undertaken study was to present the actual distribution of this species in Poland on the basis of herbarial materials. The detailed description of distribution of this species in Poland will contribute to getting full information on the western range of its occurrence in Europe.

\section{MATERIAL AND METHODS}

\section{Characterization of the object of study}

The Buxbaums sedge comes up to 0.2-0.6 (0.7) $\mathrm{m}$ and develops narrow leaves (2-4 mm wide), blue- or grey-green, shorter than its stalk. It is a loosely tufted plant with cree- ping rhizomes and rough stalks up above. Terminal spike is gynaecandrous, clavate or oblong-ovoid and clusters male flowers below $1 / 3$ to $1 / 4$ of its length (Fig. 1). Lateral spikes, numbering 2-3 (4), are solely female, ovoid or oblong-ovoid, 1-1.5 (2) cm long, and 6-10 $\mathrm{mm}$ in diameter. Female flowers comprise three stigmas. The flowering takes place in May-June, while the seeds mature in June August. Utricles are greenish-white, (3.5) 4-4.5 mm long, poorly ribbed and covered thickly with fairly large papillae. There is a beak on the top of utricle with short but usually visible teeth, which are frequently divergent. Female glumes are ovoid-linear, brown or purple, terminated in a longer or shorter awn. They are longer than utricles and largely obstruct them. Along the midrib of the female glumes there are papillas. Carex buxbaumii can make hybrids with C. hartmanii (Madalski 1960; Hegi 1967-1980; Tutin et al. 1980; Egorova 1999).

In the critical examination of the herbal material $C . b u$ xbaumii (1) was distinguished from $C$. hartmanii (2) mainly on the basis of the form of spikes $(1-$ terminal spike clavate, lateral oblong-ovoid; 2 - spikes cylindrical, longer and narrower than those of $C$. buxbaumii), the number of male flowers in terminal spike $(1$ - considerable, $2-$ a few male ones or only female ones), the length of utricles (1 (3.5) $4-4.5 \mathrm{~mm} ; 2-2.7-3.5 \mathrm{~mm}$ ), the symmetry of female glumes (1 - asymmetric; 2 - symmetric) and the presence of papilla on the midrib of female glumes $(1$ - present; 2 absent).

\section{General distribution}

On the grounds of general distribution, Carex buxbaumii may be included among the Holarctic geographical element and Circumboreal subelement. This sedge occurs in 


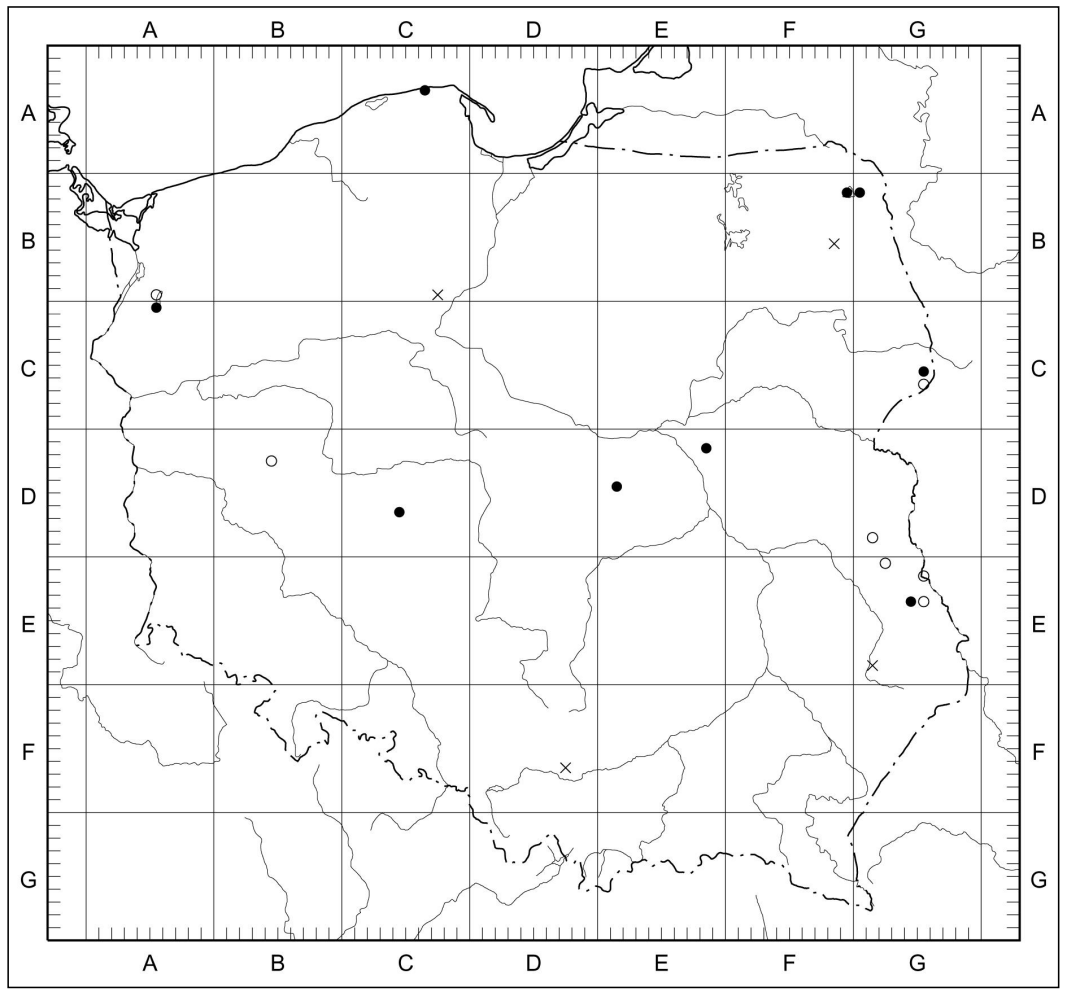

Central, Northern and North-Western Europe, Central Asia, with disjunction between the Bajkal Lake and the Kuril Islands, as well as in the central part of the North America, except the uplands separating vast areas of lowlands from the Rocky Mountains. This taxon has been also reported from Australia, but, probably it was mistaken for C. tarumensis (Hultén 1958; Meusel et al. 1978; Hultén and Fries 1986; Egorova 1999).

\section{Methods}

Carex buxbaumii has been often misidentified. In this paper its distribution is presented on the basis of a revision of the herbarial materials and my own collection. From among the literature data, only those have been used that refer to sites documented with correctly identified herbarium material. The revised material came from the following herbarial collections: BIL - Bialowieza; KRA - Jagiellonian University, Krakow; KRAM - Polish Academy of Sciences, Krakow; KTU - Silesian University; LBL - Maria Curie-Skłodowska University, Lublin; LOD - Łódź University; OLS - Warmińsko-Mazurski University, Olsztyn; POZ - Adam Mickiewicz University, Poznan; SZCZ - Agricultural Academy, Szczecin; SZUB - Szczecin University; TRN - Mikołaj Kopernik University, Torun; UGDA - Gdańsk University; WA - Warsaw University; WRAB - Agricultural Academy, Wrocław; WRSL - Wrocław University; WSRP - Podlaski University, hb. Woł. - Dan Wołkowycki collection.

The distribution map was made using the $10 \times 10 \mathrm{~km} \mathrm{AT-}$ POL grid square system (Zając 1978). The localities of this species are arranged according to the same system. Where no settlements exist at present, the name of the nearest village is given in square brackets. Habitat details are based on information from the descriptions on herbarium labels, the literature and the author's own observations.
Fig. 1. Carex buxbaumii Wahlenb. $x$ station historical o station should be confirmed

- presently existing station

\section{RESULTS}

As a result of the revision it was found that not only historical material was incorrectly identified but the same is true also for the currently collected plants. In the pre-war German herbarial plates Carex buxbaumii and C. hartmanii were repeatedly treated together and labelled as C. buxbaumii. In Poland there are only 22 well documented sites of Buxbaum sedge species occurrence. From among the reported sites, 9 are recent, 7 should be confirmed, while the others were reported many years ago and have not been confirmed so they can be treated as historical with a high probability of being correct. The eldest herbarium sheets come from before World War II and document materials collected from the vicinity of Brodło - 1885, Łowinek 1888 and Rajgród -1935.

In Poland the Buxbaum sedge occurs in dispersion (Fig. 2). The greatest number of its localities has been found in the eastern part of the country in the Lublin region and Suwatki region. Moreover, the plant is known from Podlasie, Kaszuby and Szczecin coastal belts, Mazowsze, Wielkopolska and Małopolska. Besides occurring in its own community Caricetum buxbaumii, this species is sometimes found in phytocenoses of wet meadows from the order Molinietalia. The populations of this sedge occupy rather small areas and often are in slow recess. This plant is very sensitive to changes in water conditions and poorly competitive in relation to high perennial plants. A serious threat for many sites is willow thicket, high sedges and moor grass that grow within their direct vicinity.

\section{List of localities in Poland present and historical}

Explanations: n. - near; bet. - between; res. - reserve; for. sec. - forest section 


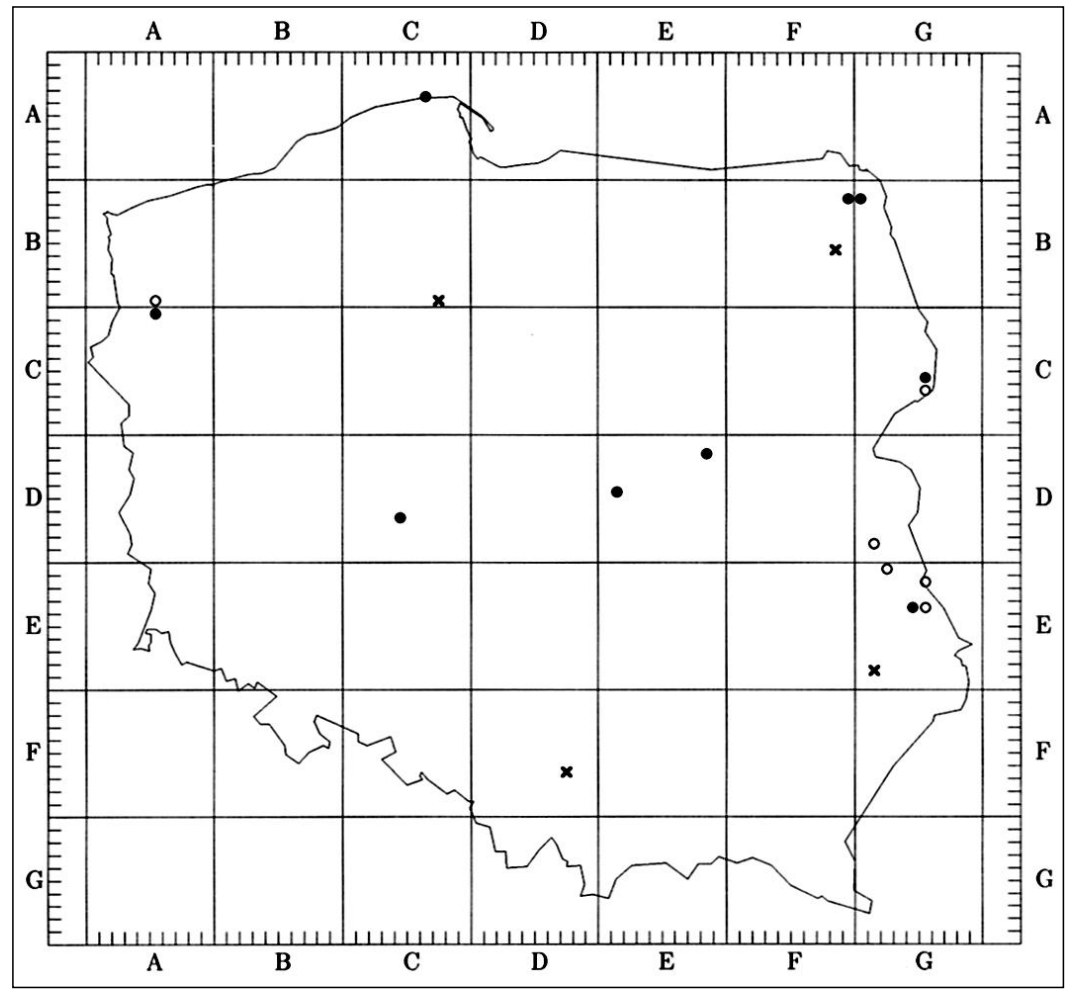

Fig. 2. Distribution of Carex buxbaumii Wahlenb. in Poland. $\times$ station historical

o station should be confirmed

- presently existing station

GRID SQUARE AB: Prov. Zachodniopomorska. 95 - Lake Miedwie - Dębina, leg. F. Celiński 1962 (POZ);

GRID SQUARE AC: Prov. Zachodniopomorska. 05 - Lake Miedwie - Ryszewo, leg. J. Mądalski 1954 (KRAM), Lake Miedwie - Grędziec - Wierzbno, leg. M. Jasnowski 1960 (SZCZ), leg. W. Bacieczko 1994, 2005 (SZCZ);

GRID SQUARE BD: Prov. Wielkopolska. 24 - n. Elżbieciny, leg. A. Patczyński 196? (WRAB);

GRID SQUARE CA: Prov. Pomorska. 36 - res. "Piaśnickie Łąki”, leg. M. Herbichowa 1979, 1980 (UGDA), leg. A. Budyś 2001 (UGDA), leg. M. Stasińska, Z. Sotek 2005 (SZUB);

GRID SQUARE CB: Prov. Kujawsko-Pomorska. 97 - n. Łowinek [Lowinneker Wald], leg. Grütter 1888 (TRN); GRID SQUARE CD: Prov. Wielkopolska. 64 - Taczanów Forest, for. sec. 200, leg. J. Pawtowski 2004 (POZ); GRID SQUARE DF: Prov. Małopolska. 67 - bet. Brodła Poręba-Zegoty, leg. B. Gustawicz 1885 (KRAM); GRID SQUARE ED: Prov. Mazowiecka. 18 - Długa Szlachecka, leg. Z. Głowacki 1978 (WSRP); Prov. Łódzka. 41 - Forestry Management - Skierniewice, Bolimów Forest (Uroczysko Grabina), leg. W. Pisarek 1983 (LOD); GRID SQUARE FB: Prov. Podlaska. 19 - Wigry National Park - Bryzgiel, leg. A. Sokołowski 1982 (BIL), leg. T. Szarejko 1999 (OLS), Wigry National Park - Krusznik (Jurkowy Róg Peninsula), leg. T. Szarejko 1999 (OLS); 58 - n. Rajgród, Forestry Tajno, leg. K. Lubliner 1935 (WA); GRID SQUARE GB: Prov. Podlaska. 10 - Wigry National

Park - Łapa Peninsula, leg. A. Sokołowski 1984 (BIL); GRID SQUARE GC: Prov. Podlaska. 55 - Białowieża Forest - Niedźwiedziówka, for. sec. 317B, leg. A. Sokołowski 2001 (BIL); 65 - Białowieża Forest - Forestry Management - Zwierzyniec, for. sec. 470D, leg. A. Sokołowski 1965 (BIL);
GRID SQUARE GD: Prov. Lubelska. 81 - Uhnin, leg. D. Fijatkowski 1951 (LBL);

GRID SQUARE GE: Prov. Lubelska. 02 - Wytyczno n. Włodawa (Krowie Bagno), leg. D. Fijałkowski 1951, 1957 (LBL), 15 - Uhrusk, leg. D. Fijałkowski 1958 (LBL), 34 n. Serebryszcze leg. D. Wotkowycki 2004 (hb. Woł.), 35 Kamień n. Chełm, leg. D. Fijałkowski 1958 (KRAM), 81 Szczebrzeszyn, leg. J. Motyka 1949 (LBL).

\section{DISCUSSION}

The Buxbaum sedge has been very often misidentified in the data from Poland and its real range has been unknown. The map presented in the "Atlas of vascular plants distribution in Poland" (Zając and Zając 2001) presents together the two often mistaken taxons Carex buxbaumii and $C$. hartmanii. Verification of the herbarial materials has provided information on the actual range of $C$. buxbaumii. On the basis of the revision it has been concluded that the map presented in the above-mentioned atlas reflects mainly the distribution of $C$. hartmanii, a much more often noted species. Similar problems in determination of correct distribution of this species have been met in Germany. Therefore, besides the maps of distribution of both sedge species there is also a map of $C$. buxbaumii aggregate (Benkert et al. 1998).

In Poland, the localities of $C$. buxbaumii are scarce and scattered. Over half of them are in the eastern part of the country, the species is even rarer in the other parts. A similar type of distribution is observed in eastern Germany, however, the sites are not so concentrated and their number is much lower (Benkert et al. 1998). As in Poland, the localities of this species are mainly found in the northern, central 
and southern part of the country. On the basis of the general range of the species (Hultén 1958; Meusel et al. 1978; Hultén and Fries 1986) and its distribution in Poland and Germany, it is possible to draw conclusions on the development of its distribution in the areas at the western limit of its range of occurrence.

Some of the verified herbarial material comes from the areas on limy substrata, e.g. near Lake Miedwie, in the Wigierski National Park or in the Lublin region. In these areas the Buxbaum sedge grows mainly on marshes developed from fen peat, occurring frequently on lacustrine chalk deposits (Jasnowski 1962; Fijałkowski, Chojnacka-Fijałkowska 1990; Jutrzenka-Trzebiatowski et al. 2001), but sometimes also on fen peat of neutral pH (Fijałkowski, Chojnacka-Fijałkowska 1990).

In some European countries the Buxbaum sedge is recognized as an endangered species, e.g. in the Czech Republic (Holub and Procházka 2000), and Germany (Fukarek 1992, Benkert and Klemm 1993). In Poland, this plant is to be found in the list of endangered taxa (Zarzycki and Szelag 1992). The majority of localities of this plant occupy small areas and many a time are under gradual decline. An example can be the population at Lake Miedwie in the projected "Miedwiański Brzeg" nature reserve. The patches of Caricetum buxbaumii association occurring there in 19561960 occupied an area of about $1000 \mathrm{~m}^{2}$ (Jasnowski 1962), whereas in 1994 just scarcely $50 \mathrm{~m}^{2}$ (Bacieczko 1996). The observed rate of population disappearance makes the basis of a supposition that the localities noted before World War II and shortly after the war and not confirmed recently can be treated as historical. The localities reported in the 1950s and 1960s should be verified.

Preservation of the few existing populations is possible only under active protection. The dynamic growth of rush plants and willow thicket should be reduced wherever necessary, changes in water conditions should be prevented, the spread of tall sedges and moor grass growing in the neighbourhood of $C$. buxbaumii patches should be restricted.

\section{CONCLUSIONS}

The verification of the herbarial material of Carex buxbaumii has allowed the conclusion that in Poland this species is rare and occurs at scattered localities over the country. Analysis of the localities in Poland and Germany gives cohesive information on the development of the western range of its occurrence in Europe. Populations of $C . b u$ xbaumii usually occupy small areas and are often under gradual decline. Their preservation requires active protection aimed to restrict the excessive spread of competing species and to maintain the water conditions. Because of the occurrence in a few localities and a high risk of their decline this species should be included in the Polish Red Book of Plants, at least as an endangered species.

\section{LITERATURE CITED}

BACIECZKO W. 1996. Zmiany antropogeniczne zespołu Caricetum Buxbaumii Issler 1932 w projektowanym rezerwacie Miedwiański Brzeg na Pomorzu Zachodnim. - Bad. Fizjogr. Pol. Zach. Ser. B. 45: 181-188. (in Polish with English summary)

BENKERT D., FUKAREK F., KORSCH H. (Hrsg.). 1998. Verbreitungsatlas der Farn- und Blütenpflanzen Ostdeutschlands. Gustav Fischer. Jena, Stuttgart, Lübeck, Ulm. pp. 615.

BENKERT D., KLEMM G. 1993. Rote Liste Farn- und Blütenpflanzen. In: Rote Liste: Gefährdete Farn- und Blütenpflanzen, Algen, und Pilze im Land Brandenburg. Hrsg.: Ministerium für Umwelt, Naturschutz und Raumordnung des Landes Brandenburg: 7-95.

EGOROVA T.V. 1999. The sedges (Carex L.) of Russia and adjacent states (within the limits of the former USSR). Russian Academy of Sciences Komarov Botanical Institute. St. Petersburg-St. Louis, pp. 772.

FIJAŁKOWSKI D., CHOJNACKA-FIJAŁKOWSKA E. 1990. Zbiorowiska z klas Phragmitetea, Molinio-Arrhenatheretea i Scheuchzerio-Caricetea fuscae w makroregionie lubelskim. Rocz. Nauk. Rol. 217: 5-415. (in Polish with English summary)

FUKAREK F. (ed.). 1992. Rote Liste der gefährdeten Höheren Pflanzen Mecklenburg-Vorpommerns. pp. 64. GoldschmidtDruck. Schwerin.

HEGI G. 1967-1980. Illustrierte Flora von Mittel-europa. Band 2. Angiospermae. Monocotyledones 2. Teil 1. 405.

HOLUB J., PROCHÁZKA F. 2000. Red List of vascular plants of the Czech Republic - 2000. Preslia 72(2-4): 187-230.

HULTÉN E. 1958. The amphiatlantic plants and their phytogeographical connections. Kungl. Svenska Vetenskapsakademiens Handlingar, Fjarde Serien. 7(1): 1-340.

HULTÉN E., FRIES M. 1986. Atlas of North European vascular plants, north of the tropic of Cancer. 1. xviii +498 pp. Koelz Scientific Books, Königsstein.

JASNOWSKI M. 1962. Budowa i roślinność torfowisk Pomorza Szczecińskiego. Szczec. Tow. Nauk. Wydz. Nauk Przyr.-Roln. 10: pp. 340.

JUTRZENKA-TRZEBIATOWSKI A., SZAREJKO T. 2001. Zespół Caricetum buxbaumii w Wigierskim Parku Narodowym. Fragm. Flor. Geobot. Polonica 8: 149-171. (in Polish with English summary)

MĄDALSKI J. 1960. Atlas Flory Polskiej i Ziem Ościennych. Cyperaceae-Cariocideae. 3 (3), pp. $65+35$ tabl. Państwowe Wydawnictwo Naukowe. Warszawa-Wrocław. (in Polish and Latin)

MEUSEL H., JÄGER E., RAUSCHERT S., WEINERT E. 1978. Vergleichende Chorologie der Zentraleuropäischen Flora. 2. Fischer, Jena. pp. 259-421.

TUTIN T.G., HEYWOOD V.H., BURGES N.A., MOORE D.M., VALENTINE D.H., WALTERS S.M., WEBB D.A. 1980 Flora Europaea. 5. Alismataceae to Orchidaceae (Monocotyledones). Cambridge University Press. pp. 452.

ZAJĄC A. 1978. Atlas of distribution of vascular plants in Poland (ATPOL). Taxon 27(5-6): 481-484.

ZAJAC A., ZAJAC M. (ed.). 2001. Atlas rozmieszczenia roślin naczyniowych w Polsce. Distribution Atlas of Vascular Plants in Poland. pp. 715. (in Polish and English)

ZARZYCKI K., SZELĄG Z. 1992. Czerwona lista roślin naczyniowych zagrożonych w Polsce. In: Zarzycki K., Wojewoda W., Heinrich Z. (ed.). Lista roślin zagrożonych w Polsce. PAN, Instytut Botaniki im. W. Szafera. Kraków. 87-98. (in Polish with English summary) 